\title{
Detection of virulence genes, antibiotic resistance genes, plasmid profile and molecular typing among Vibrio vulnificus isolated from Malaysian seawater and sediment
}

\author{
Ashraf Abbas Drais" ${ }^{* 1}$, Merriam Ghadhanfar Alwan" ${ }^{\text {"1 }}$, Anmar hameed

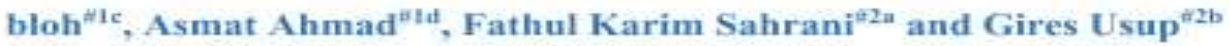 \\ \#1 School of Biosciences and Biotechnology, Faculty of Science and \\ Technology, Uniyersity Kebangsaan Malavsía (UKM), 43600 UKM Bangi, \\ Selangor, Malaysia.
}

\#1 a ashrafabbas10/amail.com

\#1b merriamghadhanfar a yahoo.com

\#1c anmarhameed ayahoo.com

\#1d. asmattaukm.edu.my

\#2 School of Environmental \& Natural Resource Sciences, Faculty of Science

\& Technology; The National University of Malaysia, 43600 UKM Bangi,

Selangor, Malaysia.

\#2a fathuliakm-edu.my

\#2b gires@akm.edu.my

\section{ABSTRACT:}

This study was aimed to investigate the presence of virulence genes, antibiotic resistance genes and molecular diversity of $V$. vulnificus isolated from several coastal areas in Malaysia. Fifty - five isolates were first tested for the presence of seven virulence genes including Hemolysin ( $v v h \mathrm{~A})$, Extracellular Capsule Polysaccharide (CPS) ( $h p 1)$, Virulence correlated gene $(v c g)$, Virulence regulator gene (tox $\left.\mathrm{R}_{\mathrm{y}}\right)$, Cytotoxin gene ( $\left.r t x \mathrm{~A}\right)$, Metalloprotease ( $v v p$ E) and Pili gene (pilA). Hundred percent of tested seawater isolates were carrying pil A gene, followed by $87.5 \%$ for both $v v p \mathrm{E}$ and $v v h \mathrm{~A}$ genes. While, $100 \%$ of sediment isolates were having $v c g$ and $v v h \mathrm{~A}$ genes. The presence of 7 antibiotic resistance genes including Streptomycin (str B), B-lactamase (blaP1), Chloramphenicol (floR), Tetracycline (tet A), Erythromycin (ermB), Quinolone resistance protein $(q n r \mathrm{~A})$ and Aminoglycosides (aac(3)- IIa) were investigated. In seawater, $65 \%$ of isolates were having blaP 1 gene, and the lowest percentage was found to be $7.5 \%$ of the erm $\mathrm{B}$ gene while $66.66 \%$ of sediment isolates were carrying blaP1 gene and the lowest percentage was $13.33 \%$ of str B gene. The plasmid sizes that detected in this study were ranging from $2.7 \mathrm{~kb}$ to $25.4 \mathrm{~kb}$ even though 6 of the isolates were plasmidless. The RAPD-PCR analysis of typable $V$. vulnificus isolates showed 6 clusters and 3 single isolates. The ERIC-PCR analysis of typeable $V$. vulnificus has divided the isolates into 11 clusters and 10 single isolates. The results of this research have given information of the presence of $V$. vulnificus that carry the factors of virulence and resistance to many classes of antibiotics are directed in the recreational areas of what causes a potential risk of infections and this bacteria might driven from the sewage and /or medical waste disposal and suggesting the regular monitoring of this bacteria in coastal areas.

Key word: Vibrio vulnificus, virulence genes, antibiotic resistance genes, plasmid profile, RAPD and ERIC PCR.

Corresponding Author: Drais. A. A.(Ashraf Abbas Drais) 


\section{INTRODUCTION}

Vibrio vulnificus is a gram negative an opportunistic human pathogen that naturally inhabits estuarine and coastal waters worldwide. This bacterium has been ubiquitous in these environments and isolated from seawater, sediments, fish, and shellfish such as bivalve molluscs aquatic beards and mammals (including humans) being found as free living bacteria in marine waters [1]. This organism is halophilic, and it is routinely found in waters of estuarine environments as part of the normal microflora, as well as in oysters. Other shellfish inhabiting brackish waters in estuaries is a diverse species of moderately halophilic marine bacteria that is found in tropical and warm waters with morphology of curved motile rods and a single motile polar flagellum. More than 100 strains of this bacterial species have been reported and it is rational that several thousands of them still exist [2]. The species also displays diverse lifestyles. Previous studies have reported that $V$. vulnificus strains possess pathogenic potential for humans and aquatic animals, such as shrimp [3] and eels [4, 5, 6, 7].

$V$. vulnificus is virulent for humans and fish. In terms of virulence, V. vulnificus isolates are classified into three biotypes, two of which, biotypes 1 and 3 are classified as human isolates and biotype 2 is classified a fish and eel isolates. There are various factors implicated as possible virulence determinants for $V$. vulnificus, CPS is considered a major virulence factor of $V$. vulnificus which allows survival of the bacteria in the human host [8]. The epimerase gene is essential for capsule expression in V. vulnificus [9], extracellular enzymes include hemolysin, cytolysin, and elastolytic protease. The ability of $V$. vulnificus to cause a disease is linked to the production of a large cytotoxin called the "multifunctionalautoprocessing RTX" (MARTXVv) toxin [10, 11, 12]. The capability of bacterial adherence to the host cells is another important virulence factor for many pathogens, including $V$. vulnificus. Moreover, NanA gene is obviously crucial for the growth and adhesion of $V$. vulnificus during infection of mice [13].

Plasmids are important in certain bacteria since they code for proteins, especially enzymes, which can confer resistance to antibiotics. Strains of $V$. vulnificus possess one or more virulence plasmids with molecular mass that ranges between 68 and $70 \mathrm{~kb}$. Virulence in fish seems to rely on a recently described plasmid that can be transmitted between strains by a conjugative plasmid $[14,15]$. V. vulnificus strains were also found to carry more than plasmids with diverse sizes that carrying virulent elements [16].

Traditionally, Vibrio is highly susceptible to virtually all antimicrobials. However, recently, antimicrobial resistance has emerged and evolved in many bacterial genera due to the excessive use of antimicrobials in human, agriculture, and aquaculture systems [17]. In contrast, previous research has not documented the awareness of antimicrobial-resistant bacteria in the aquatic environment adequately. The only extensive investigation of antimicrobial susceptibility in V. parahaemolyticus in the United States had occurred in 1978, even before $V$. vulnificus was first recognized as a food-borne pathogen [18]. A few recent studies examining the antimicrobial susceptibilities of non-cholerae Vibrio spp. and other aquatic bacteria have been carried out in other countries, but with a very limited number of either V. parahaemolyticus or V. vulnificus isolates isolated from Saudi Arabia included in their investigation $[16,19,20]$.

Molecular techniques for Vibrio identification and subtyping have been developed, including DNA microarray technologies and PCR-based methods which target species-specific determinants. PCR-based molecular-typing studies have been performed with amplified fragment length polymorphism (AFLP), enterobacterial repetitive intergenic consensus (ERIC)-PCR and randomly amplified polymorphic DNA (RAPD) analysis [21]. Therefore, the current study aimed to determine the presence of virulence genes, antibiotic resistance genes, plasmid and study the molecular characterization of $V$. vulnificus from seawater and sediment samples from Malaysia. 


\section{Materials and Methods}

Sampling sites and samples collection:

Sampling sites were carefully selected and included ten recreational sites of four different public beaches of West Malaysia (Bachok, Kelantan; Port Klang, Mersing, Johor; Selangor; Port Dickson, Negeri Sembilan) see figuer1. Typically, water samples were collected mornings $(9-11 \mathrm{am})$ at $50 \mathrm{~cm}$ water depths using sterile $500 \mathrm{~mL}$ Schott bottles following the hand-dip method [22]. Sediment samples were collected as described by [23], sterile disposable plastic containers and $100 \mathrm{ml}$ vials were used to collect sediments from the sampling stations and carefully forcing them into the sand at about $10 \mathrm{~cm}$ depth. All Samples were maintained at a temperature of 1 to $10{ }^{\circ} \mathrm{C}$ in a pre-chilled cooler containing sufficient cold artificial ice and transferred to the laboratory within 2-5 h.

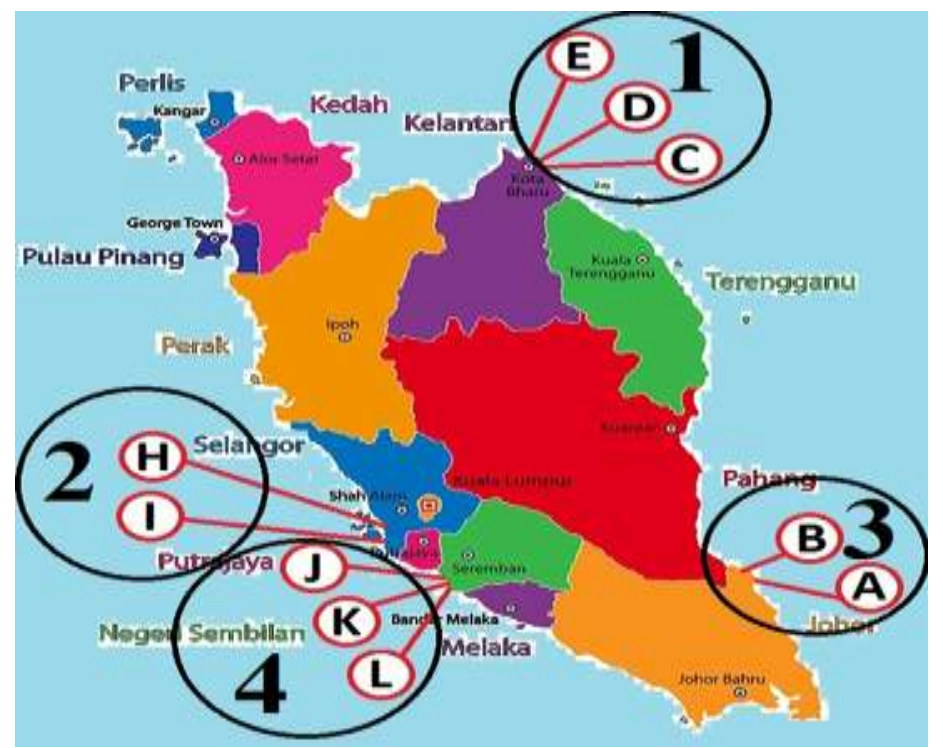

Fig 1. Map of Malaysia and sampling station sites; 1: Bachok, Kelantan; 2: Port Klang; 3: Mersing, Johor; 4: Port Dickson, Negeri Sembilan

Bacterial isolation and identification:

For isolation and identification, serial dilution method and spreading plate technique were used for growing V. Vulnificus. Two media were used for isolation and identification: Thiosulfate Citrate Bile Salts Sucrose Agar -TCBS (Oxoid, UK) and Chromogenic Vibrio Agar CV (Titan Media, India). The typical colonies that were assumed to be V. Vulnificus that have shown green color on TCBS agar and mauve on CV agar were then subjected to biochemical tests that designed by following Bergey's manual and FDA manual [24]. All the isolates were maintained on Trypticase Soy Agar TSA (Oxoid, UK) plates at $4{ }^{\circ} \mathrm{C}$ and for long-term storage in Trypticase soy broth TSB (Oxoid, UK) containing $40 \%$ glycerol at -70 ${ }^{\circ} \mathrm{C}[25]$.

DNA extraction:

DNA extraction was conducted by DNA Purification Kit (Promega, USA) as described in the manufacturer's manual. The identified $V$. vulnificus isolated were then grown in $5 \mathrm{ml}$ of Lauria Bertani (LB) broth (Oxoid, UK) at $35{ }^{\circ} \mathrm{C}$ for $20 \mathrm{~h}$. The extracted genomic DNA was then stored at $4{ }^{\circ} \mathrm{C}$ for further studies.

Plasmid isolation: 
For plasmid extractions, $V$. vulnificus were grown overnight in LB broth with an addition of 4 $\%$ (w/v) $\mathrm{NaC} 1$ at $35{ }^{\circ} \mathrm{C}$, and the plasmids were extracted with the FavorPrep ${ }^{\mathrm{TM}}$ Plasmid Extraction Mini Kit (FAVORGEN BIOTECH CORP., Taiwan) to get the high-quality plasmid DNA following manufacturer's instruction. The yield of this process were then loaded in $1 \%(\mathrm{w} / \mathrm{v})$ agarose gel. The gel electrophoresis was run at $80 \mathrm{~V}$ for 1 hour, and DNA marker, $1 \mathrm{~kb}$ Extend DNA ladder (New England BioLabs, USA) was used. The gel was then visualiz under UV light through gel documentation of GeneSys G: BOX EF2 (Syngene, USA). The gel image was recorded and analyzed [26]. The plasmid DNA products were stored at $-20^{\circ} \mathrm{C}$ for further analysis

PCR amplification of virulence genes:

Screening for the presence of virulence genes among $55 \mathrm{~V}$. vulnificus isolates (40 recovered from seawater and 15 from sediments) was done. Polymerase Chain Reactions (PCR) were conducted to amplify hemolysin ( $v v h \mathrm{~A})$, Extracellular Capsule Polysaccharide CPS (hp1), virulence correlated gene $(v c g)$, virulence regulator gene $\left(t o x \mathrm{R}_{V v}\right)$ cytotoxin gene $(r t x \mathrm{~A})$, metalloprotease $(v v p \mathrm{E})$ and pili gene (pilA) $[27,28,29,3031,32,33]$. The primes list and PCR reaction conditions were listed in table 1 and table 2, respectively. Positive control ( $V$. vulnificus ATCC 27562) and negative control (E.coli ATCC 25992) were used in this study. All reactions were conducted in a Mastercycler ${ }^{\circledR}$ thermal cycler (Eppendorf, Germany). Gel electrophoresis assay was done by mixing $10 \mu \mathrm{L}$ of the amplicon with $2 \mu \mathrm{L}$ of gel loading dye and electrophoresed in pre-stained $1.0 \%$ agarose (Sigma Aldrich, USA) for $1 \mathrm{~h}$ at $85 \mathrm{~V}$ in 1x Tris-Acetate - Ethylenediaminetetraacetic acid (TAE) buffer (FirstBase Sdn Bhd, Malaysia). The 100bp and $1 \mathrm{~kb}$ DNA ladders (Invitrogen, Belgium) was used as a molecular size marker.

Table 1. Primer used to detect virulence genes in this study

\begin{tabular}{|lcl|}
\hline \multicolumn{1}{|c}{ Gene name } & $\begin{array}{c}\text { Primer } \\
\text { name }\end{array}$ & \multicolumn{1}{c|}{ Primer sequence (5' to 3') } \\
& & \\
\hline Hemolysin $(v v h \mathrm{~A})$ & $v v h \mathrm{~A}-\mathrm{F}$ & CCGCGGTACAGGTTGGCGCA \\
& $v v h \mathrm{~A}-\mathrm{R}$ & CGCCACCCACTTTCGGGCC \\
Extracellular Capsule Polysaccharide & $h p 1-\mathrm{F}$ & TTTGGGATTTGAAAGGCTTG \\
(CPS) $(h p 1)$ & $h p 1-\mathrm{R}$ & GTGCCTTTGCGAATTTTGAT \\
Virulence correlated gene $(v c g)$ & $v c g C-\mathrm{F}$ & AGCTGCCGATAGCGATCT \\
& $v c g \mathrm{C}-\mathrm{R}$ & TGAGCTAACGCGAGTAGTGAG \\
Virulence regulator gene $\left(t o x \mathrm{R}_{v v)}\right.$ & toxR-F & GASTTTGTTTGGCGYGARCAAGGTT \\
& $t o x \mathrm{R}-\mathrm{R}$ & AACGGAACTTAGACTCCGAC \\
Cytotoxin gene $(r t x \mathrm{~A})$ & $r t x \mathrm{~A}-\mathrm{F}$ & CGGGATCCTATGGCGTGAACGGCGAAG \\
& $r t x \mathrm{~A}-\mathrm{R}$ & CGGGATCCAGCAGCCACAAGCGATTC \\
Metalloprotease $(v v p \mathrm{E})$ & $v v p \mathrm{E}-\mathrm{F}$ & GTCGCGGAAGAAGAGCC \\
& $v v p \mathrm{E}-\mathrm{R}$ & GGCCGTGAGAGCACTCCGG \\
& $p i l \mathrm{~A}-\mathrm{F}$ & TGGCTGCTGTTGCTATTC \\
& $p i l \mathrm{~A}-\mathrm{R}$ & GGTCCACCACTAGTACCAAC \\
\hline
\end{tabular}


Table 2. PCR conditions of detection of virulence genes

\begin{tabular}{|c|c|c|c|c|c|c|c|c|}
\hline $\begin{array}{l}\text { Gene } \\
\text { name }\end{array}$ & $\begin{array}{l}\text { Size } \\
\text { (bp) }\end{array}$ & $\begin{array}{c}\text { Pri } \\
\text { me } \\
\mathbf{r} \\
\text { Co } \\
\text { nc. }\end{array}$ & $\begin{array}{c}\operatorname{dnT} \\
P \\
(\mu \mathrm{M})\end{array}$ & $\begin{array}{c}\text { Taq } \\
\text { poly. } \\
\text { (unit } \\
\text { s) }\end{array}$ & $\begin{array}{c}\mathrm{MgCl} \\
2 \\
(\mathrm{mM} \\
)\end{array}$ & $\begin{array}{c}\text { B } \\
\text { uf } \\
\text { fe } \\
r\end{array}$ & $\begin{array}{c}\text { Anne } \\
\text { al } \\
\text { Tem } \\
\text { p } \\
\left({ }^{\circ} \mathrm{C}\right)\end{array}$ & Reference \\
\hline vvhA & 519 & 0.5 & 200 & 0.04 & 2.0 & $1 \mathrm{x}$ & 57 & M34670, NCBI \\
\hline hp1 & 342 & 0.5 & 200 & 0.04 & 2.0 & $1 \mathrm{x}$ & 57 & DQ360502, NCBI \\
\hline$v c g$ & 99 & 0.5 & 200 & 0.04 & 2.0 & $1 \mathrm{x}$ & 57 & AY626575, NCBI \\
\hline $\operatorname{tox}_{V_{V}}$ & 435 & 0.5 & 200 & 0.04 & 2.0 & $1 \mathrm{x}$ & 57 & 25 \\
\hline$r t x A$ & 1440 & 0.5 & 200 & 0.04 & 2.0 & $1 \mathrm{x}$ & 61 & 28 \\
\hline$v v p \mathrm{E}$ & 426 & 0.5 & 200 & 0.04 & 2.0 & $1 \mathrm{x}$ & 55 & 31 \\
\hline pilA & 217 & 0.5 & 200 & 0.04 & 2.0 & $1 \mathrm{x}$ & 50 & 30 \\
\hline
\end{tabular}

PCR amplification of antibiotic resistance genes:

All $V$. vulnificus isolates $(\mathrm{n}=55)$ from both, seawater and sediment samples were screened first phenotypically by using 14 different antibiotics \{Ampicillin AM (10 $\mu \mathrm{g})$, Amoxicillin AX $(10 \mu \mathrm{g})$, Chloramphenicol C $(30 \mu \mathrm{g})$, Ciprofloxacin CIP $(10 \mu \mathrm{g})$, Gentamycin CN $(10 \mu \mathrm{g})$, Erythromycin E $(15 \mu \mathrm{g})$, Nitrofurantion F $(200 \mu \mathrm{g})$, Kanamycin K $(30 \mu \mathrm{g})$, Cephalothin KF $(30 \mu \mathrm{g})$, Nalidixic acid NA $(30 \mu \mathrm{g})$, Penicillin P $(10 \mathrm{u})$, Carbenicillin PY $(100 \mu \mathrm{g})$, Streptomycin S $(25 \mu \mathrm{g})$ and Tetracycline TE $(30 \mu \mathrm{g})\}$ (Oxoid, UK) through disk diffusion method [34] and genotypically by PCR technique to detect the carriage of genes coding for resistance to antibiotics. The following resistant genes streptomycin resistance $(\operatorname{str} \mathrm{B}), \beta$ lactamase resistance (bla $\mathrm{P} 1)$, chloramphenicol resistance (floR), tetracycline Resistance (tet $\mathrm{A})$, erythromycin resistance $(\operatorname{ermB})$, quinolone resistance protein $(q n r \mathrm{~A})$ and aminoglycosides resistance ( $a a c(3)-I I a)$ were employed in this investigation for detection of genes responsible for resistance and previously described by [35, 36, 37, 38]. The primes list and PCR reaction conditions were listed in table 3 and table 4, respectively. All reactions were conducted in a Mastercycler ${ }^{\circledR}$ thermal cycler (Eppendorf, Germany). Positive and negative controls were included for each set of amplifications. A $100 \mathrm{bp}$ and $1 \mathrm{~kb}$ DNA ladder (Invitrogen, Belgium) was used as a molecular size marker.

Table 3. Primers used for detection of antibiotic resistance genes in $V$. vulnificus

\begin{tabular}{|lll|}
\hline Gene name & Primer name & Primer sequence (5' to 3') \\
\hline Streptomycin resistance (strB) & strB-F & CCGCGATAGCTAGATCGCGTT \\
& strB-R & CGACTACCAGGCGACCGAAAT \\
B-lactamase resistance (blaP1) & blaP1-F & GGCATCCAAGCAGCAAG \\
& blaP1-R & CTGGTTCATTTCAGATAGCG \\
Chloramphenicol Resistance (floR) & floR-F & TTATCTCCCTGTCGTTCCAGCG \\
& floR-R & CCTATGAGCACACGGGGAGC \\
Tetracycline Resistance (tetA) & tetA-F & GTAATTCTGAGCACTGTCGC \\
& tetA-R & CTGCCTGGACAACATTGCTT \\
Erythromycin resistance (ermB) & ermB-F & AGACACCTCGTCTAACCTTCGCTC \\
& ermB-R & TCCATGTACTACCATGCCACAGG \\
Quinolone resistance protein (qnrA) & qnrA-F & AATTTTAAGCGCTCAAACCTCCG \\
& qnrA-R & TCCTGTTGCCACGAGCATATTTT \\
Aminoglycosides resistance (aac(3)-IIa) & aac(3)-IIa-F & CGGCCTGCTGAATCAGTTTC \\
& aac(3)-IIa-R & AAAGCCCACGACACCTTCTC \\
\hline
\end{tabular}




\begin{tabular}{|c|c|c|c|c|c|c|c|c|}
\hline Gene & $\begin{array}{l}\text { Produ } \\
\text { ct } \\
\text { Size } \\
\text { (bp) }\end{array}$ & $\begin{array}{l}\text { Prime } \\
\mathbf{r} \\
\text { Conc. }\end{array}$ & $\begin{array}{l}\text { dnTP } \\
(\mu \mathrm{M})\end{array}$ & $\begin{array}{l}\text { Taq } \\
\text { poly. } \\
\text { (units) }\end{array}$ & $\begin{array}{l}\mathrm{MgCl}_{2} \\
(\mathrm{mM})\end{array}$ & $\begin{array}{l}\text { Buff } \\
\text { er }\end{array}$ & $\begin{array}{l}\text { Annea } \\
1 \text { Temp } \\
\left({ }^{\circ} \mathrm{C}\right)\end{array}$ & $\begin{array}{l}\text { Refere } \\
\text { nce }\end{array}$ \\
\hline strB & 515 & 0.5 & 200 & 0.04 & 2.0 & $1 \mathrm{x}$ & 64 & 49 \\
\hline blaP1 & 874 & 0.5 & 200 & 0.04 & 2.0 & $1 \mathrm{x}$ & 55 & 48 \\
\hline floR & 526 & 0.5 & 200 & 0.04 & 2.0 & $1 \mathrm{x}$ & 64 & 50 \\
\hline tetA & 950 & 0.5 & 200 & 0.04 & 2.0 & $1 \mathrm{x}$ & 60 & 51 \\
\hline ermB & 640 & 0.5 & 200 & 0.04 & 2.0 & $1 \mathrm{x}$ & 63 & 52 \\
\hline qnrA & 521 & 0.5 & 200 & 0.04 & 2.0 & $1 \mathrm{x}$ & 62 & 34 \\
\hline aac(3)-IIa & 436 & 0.5 & 200 & 0.04 & 2.0 & $1 \mathrm{x}$ & 61 & 53 \\
\hline
\end{tabular}

Molecular typing of $V$. vulnificus by RAPD-PCR:

To assess the utility of RAPD-PCR in the subtyping of $V$. vulnificus recovered during the study, all isolates were subjected to RAPD-PCR. The Gen1 5'-AGGATACGTG-3' primer [39] was used for the RAPD-PCR reactions. V. vulnificus ATCC 27562 was used as a reference, and negative controls were performed by adding $1 \mu \mathrm{l}$ of sterile ultrapure deionized water [40]. PCR amplifications were performed in $0.2 \mathrm{~mL}$ and the total volume of the reaction mixture was $50 \mu \mathrm{l}$ consisting of $25 \mu \mathrm{l} 10 \mathrm{x}$ PCR master mix $\left(\right.$ EconoTaq $^{\circledR}$ PULS GREEN 2X Master Mix, Lucigen), $0.5 \mu \mathrm{l}$ of primer and template DNA $1.0 \mu 1$, and then, the volume adjusted to the final volume by adding Nuclease Free Water (NFW). PCR conditions adopted involving initial denaturation at $95{ }^{\circ} \mathrm{C}$ for $5 \mathrm{~min}$ following by 45 cycles of denaturation at $94{ }^{\circ} \mathrm{C}$ for $1 \mathrm{~min}$, annealing for $1 \mathrm{~min}$ at $35^{\circ} \mathrm{C}$ and polymerization at $72{ }^{\circ} \mathrm{C}$ for 2 min. Final elongation was at $72{ }^{\circ} \mathrm{C}$ for 7 min [40].

\section{Molecular typing of $V$. vulnificus by ERIC-PCR:}

The ERIC-PCR assay was performed on all $V$. vulnificus isolates that recovered during the study. The PCR technique was carried out in $0.2 \mathrm{ml}$ microcentrifuge tubes, with a $50 \mu \mathrm{l}$ reaction mixture consisting of $25 \mu \mathrm{l}$ of $2 \mathrm{X}$ DreamTag Green PCR Master Mix (Thermo Scientific, USA), $1 \mu \mathrm{l}$ of $100 \mu \mathrm{M}$ of each ERIC primers as described previously by [39]; ERIC-1 (5'- CAC TTA GGG GTC CTC GAA TGT A -3') and ERIC-2 (5'- AAG TAA GTG ACT GGG GTG AGC G -3') [41],1 $\mu 1$ of approximately $100 \mathrm{ng}$ DNA template. This was followed by adjusting the volume until $50 \mu 1$ by adding nuclease-free water (NFW). Both positive and negative DNA controls were included in each reaction. The cycling conditions were as follows; pre-denaturation at $95^{\circ} \mathrm{C}$ for 7 minutes, denaturation at $90^{\circ} \mathrm{C}$ for 30 seconds, annealing at $58^{\circ} \mathrm{C}$ for 1 minute, and extension at $65^{\circ} \mathrm{C}$ for 8 minutes, with a final extension at $68^{\circ} \mathrm{C}$ for 16 minutes at the end of 30 cycles.

\section{RAPD and ERIC-PCR analysis:}

A $10 \mu \mathrm{L}$ volume of each PCR product was mixed with $2 \mu \mathrm{L}$ of loading dye and subjected to a $1 \%$ TAE buffer electrophoresis system. In each run, a molecular weight marker $100 \mathrm{bp}$ PCR ladder (Invitrogen) was included. Following photography using a UV transilluminator and the relatedness of the bacterial isolates were estimated by ERIC-PCR and RAPD-PCR according to the photographic image of the gel using ImageJ. The data obtained then were clustered 
using average linkage (UPGMA, unweighted group pair method with arithmetic averages) by using PHYLIP (version 3.697) application and the results were performed in dendrogram form.

\section{Results and Discussions}

Percentage of virulence genes of $V$. vulnificus:

The percentage of virulence genes of $V$. vulnificus from seawater and sediment isolates are presented in Figure 2 and Table 5. For $V$. vulnificus, seven virulence genes were evaluated, and analysis of the results have shown that only one gene (pilA) had $100 \%$ virulence while two other genes had a high percentage of virulence and these are genes $v v h \mathrm{~A}$ and $v v p \mathrm{E}$ which had $87.5 \%$ virulence each. The gene with the least virulence from seawater isolates was gene $r t x \mathrm{~A}$. However, two genes ( $v c g$ and $v v h \mathrm{~A}$ ) from sediment isolates have $100 \%$ virulence while $h p l$ had $93.33 \%$ virulence. The gene with the least percentage of virulence from sediment isolates was still gene $r t x \mathrm{~A}$. The low percentage of $r t x \mathrm{~A}$ virulence gene as observed in this study is in contrast with those reported by previous study [42], that found $75.5 \%$ of virulence gene to be $r t x \mathrm{~A}$ gene. The generality of the results showed that isolates from sediment have a higher percentage of virulence compared to seawater isolates and all isolate groups.

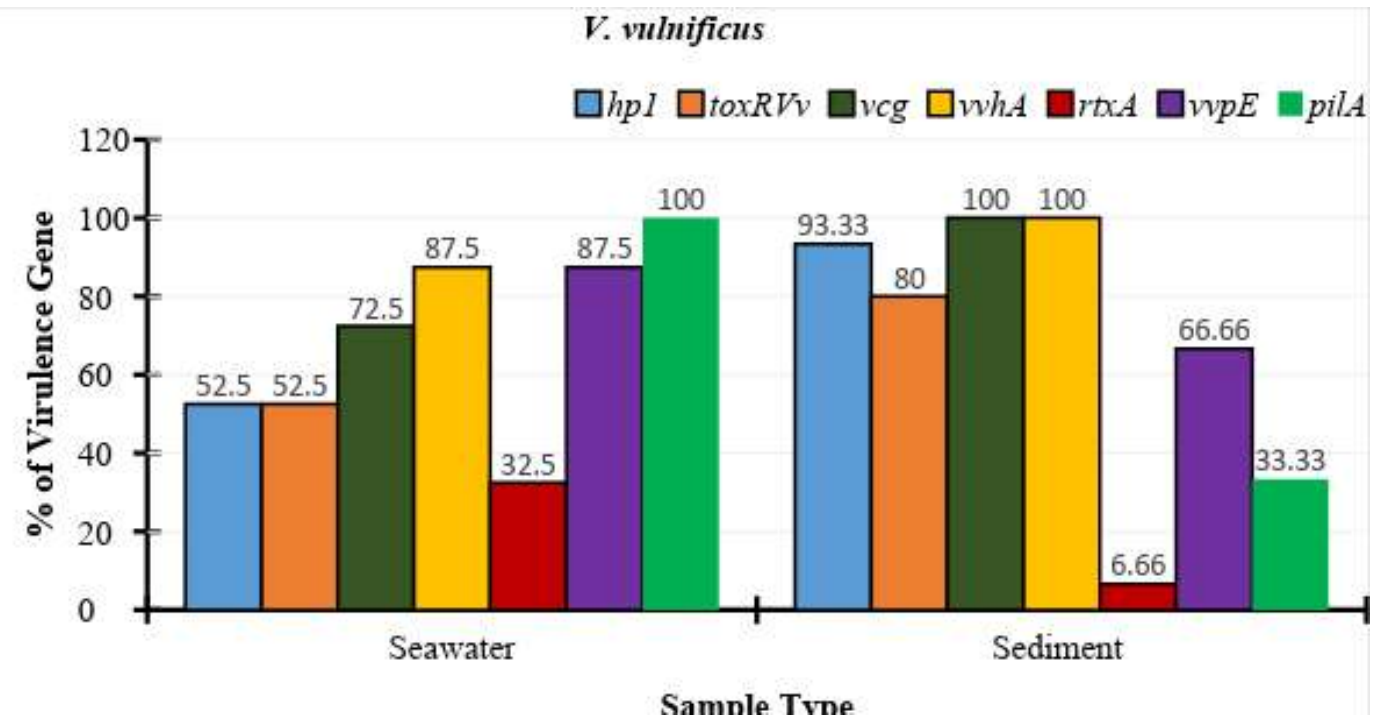

Fig 2. Percentage of virulence genes of $V$. vulnificus from seawater isolates, isolates from sediment and all isolates

Table 5. Percentage of virulence genes of $V$. vulnificus

\begin{tabular}{|c|c|c|c|}
\hline Gene & $\begin{array}{l}\text { Seawater } \\
n=40(\%)\end{array}$ & $\begin{array}{l}\text { Sediment } \\
\mathrm{n}=51(\%)\end{array}$ & $\begin{array}{l}\text { All isolates } \\
n=55(\%)\end{array}$ \\
\hline hp1 & $21(52.5)$ & $14(93.33)$ & $35(63.63)$ \\
\hline toxRVv & $21(52.5)$ & $12(80)$ & $33(60)$ \\
\hline$v c g$ & $29(72.5)$ & $15(100)$ & $44(80)$ \\
\hline vvhA & 35 (87.5) & $15(100)$ & $50(90.9)$ \\
\hline$r t x A$ & 13 (32.5) & $1(6.66)$ & $14(25.45)$ \\
\hline$v v p \mathrm{E}$ & 35 (87.5) & $10(66.66)$ & 45 (81.81) \\
\hline pilA & $40(100)$ & $5(33.33)$ & 45 (81.81) \\
\hline
\end{tabular}




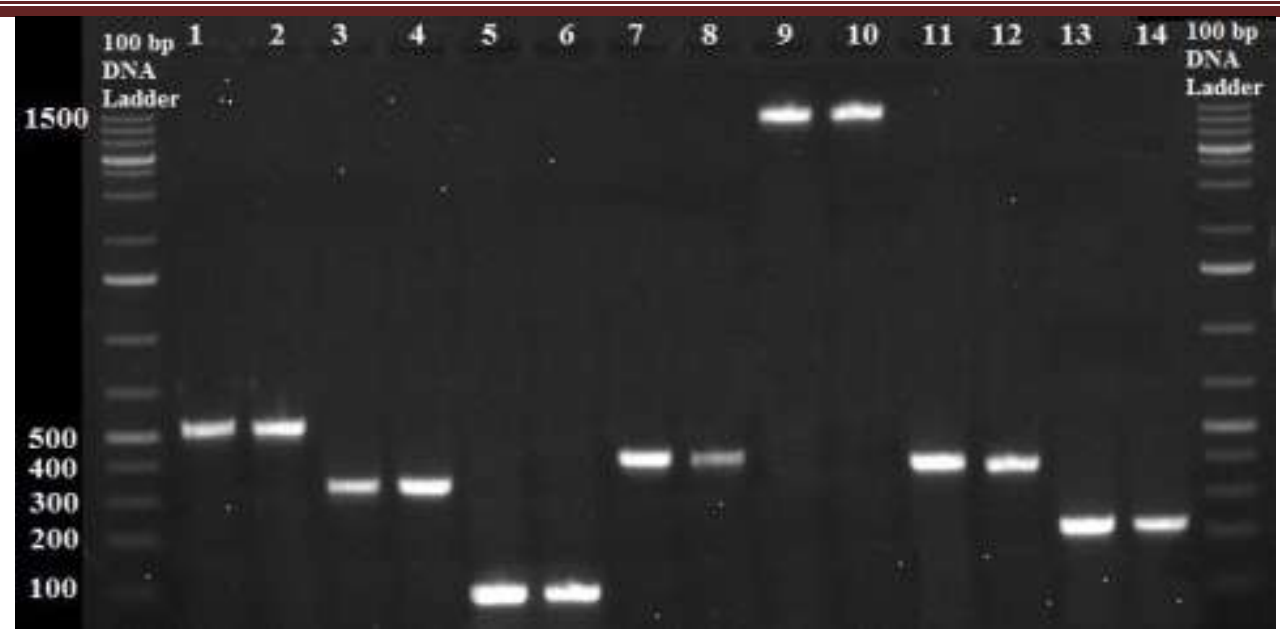

Fig 3. Detection of virulence genes in $V$. vulnificus isolates by PCR technique, electrophoresed on $1.5 \%$ (w/v) agarose gel. Lanes 1, 2: vvhA gene in VVAW2 and VVCW1. Lanes 3, 4: hp1 gene in VVKW1 and VVKW3. Lanes 5, 6: vcg gene in VVAW1 and VVAW2. Lanes 7, 8: toxR gene in VVCW3 and VVDW3. Lanes 9, 10: rtxA gene in VVCW3 and VVDW3. Lanes 11, 12: vvpE gene in VVAW2 and VVBW1. Lanes 11, 12: pilA gene in VVDW8 and VVDW9

Antibiotic resistance patterns, plasmid profile of $V$. vulnificus:

The antibiotic resistance patterns and plasmid profile of $V$. vulnificus isolated from this study is presented in Table 6. The results showed that all the isolates were resistant to at least four of the tested antibiotics, implying multi-drug resistance. This agrees with the findings of previous study [43], where multiple antibiotic resistances were reported from Vibrio isolates of different sources. Two of the isolates (VVEW1, VVKW2) were found to be resistant to 13 of the tested antibiotics. In a recent study [44], multiple drug resistance was reported from $V$. vulnificus isolates. Twenty different antibiotic resistance patterns were recorded from the $V$. vulnificus isolated in this study. The isolates have plasmid sizes ranging from $2.7 \mathrm{~kb}$ to $25.4 \mathrm{~kb}$ even though many of the isolates were plasmidless. Plasmid sizes ranging from $9 \mathrm{~kb}$ to 123 $\mathrm{kb}$ has been reported in an earlier study on Vibrio isolates [45].

Table 6. Antibiotic resistance patterns and plasmid profiling of $V$. vulnificus

\begin{tabular}{|llll|}
\hline Antibiogram & Isolate codes & $\begin{array}{c}\text { Patter } \\
\text { n }\end{array}$ & Plasmid Size (kb) \\
\hline AM, AX, C, CIP, CN, E, F, K, KF, NA, & VVEW1, VVKW2 & A & $5.4,13,25.4,35$ \\
P, PY, S & & B & $4.3,6.5,10.4$ \\
AM, AX, C, CIP, E, F, K, KF, NA & VVDW4, VVEW3, VVFW6 & C & $7.6,10.4$ \\
AM, AX, CIP, F, K, KF, NA & VVJW4, VVKW1, VVLW3 & D & $2.7,5.4,24.8$ \\
AM, CIP, F, K, P, PY, S & VVHW6, VVIW3, VVKW3, & & \\
& VVLW2 & E & $2.7,6.5,35$ \\
AM, AX, P, PY, S, TE & VVAW1, VVBW1, VVCW2, & & \\
& VVDW3, VVDW6, VVEW2, & & \\
& VVGW1, VVHW3, VVIW1, & & \\
& VVJW3, VVJW6, VVLW1 & F & N.D \\
AM, F, KF, P, PY & VVJW5, VVLW4 & G & N.D \\
AM, F, KF, P, S & VVCW3, VVKW4 & H & N.D \\
AM, F, P, PY, S & VVAW2, VVDW5, VVHW2, & & \\
AM, CIP, F, K & VVIW5 & I & N.D \\
\hline
\end{tabular}




\begin{tabular}{|llll}
\hline \hline & VVHW4, VVIW2, VVJW2 & & \\
AM, F, P, PY & VVCW5, VVDW9 & $\mathrm{J}$ & 10.4 \\
AM, CN, E, F, K, KF, NA, P, PY, S, & VVDS1, VVKS2 & $\mathrm{K}$ & $2.7,4.3,5.4,6.5,7.6,10.4$, \\
TE & & & $13,16.9,24.8,25.4,35$ \\
AM, CN, E, F, KF, NA, P, TE & VVDS2 & $\mathrm{L}$ & $4.3,7.6,25.4$ \\
AM, AX, C, CN, E, F, KF, P & VVJS2, VVLS1 & $\mathrm{M}$ & $2.7,16.9$ \\
AM, AX, CN, E, KF, P, PY & VVES2 & $\mathrm{N}$ & N.D \\
AM, AX, F, KF, P, PY & VVHS2 & 0 & $4.3,16.9$ \\
AX, CN, E, KF, P, PY & VVES2 & $\mathrm{P}$ & N.D \\
AX, CN, E, P, PY & VVBS1, VVLS2 & Q & N.D \\
AX, C, P, PY, S & VVCS2, VVES1, VVIS1 & R & N.D \\
AX, CN, P, PY & VVIS3 & S & $6.5,10.4$ \\
CN, E, P, PY & VVES3 & T & N.D \\
\hline
\end{tabular}

Percentages of antibiotic resistance genes of $V$. vulnificus:

The rate of resistance genes of $V$. vulnificus from seawater and sediment isolates were evaluated in this study, and the results are presented in figure 4, 5 and Table 7. In case of seawater isolates, the results showed that no gene from seawater isolates has $100 \%$ of resistance gene. The highest rate of resistance was obtained from blaPl which has $65 \%$ of the resistance gene, followed by strB with $60 \%$ of resistance gene. In a recent study, however, the percentage of resistance of $s t r \mathrm{~B}$ was found to be $22.2 \%$ [45]. The rest from this group have a low rate of resistance genes and the least among them was ermB with $7.5 \%$ of resistance gene. While, the sediment isolates were also showing no gene from sediment isolates with $100 \%$ of resistance gene. The highest rate of resistance was from blaPl with $66.66 \%$ of resistance followed by ermB with $53.33 \%$ of resistance gene. The rest of the genes in this group have a low rate of resistance and the least was from strB with $13.33 \%$ of resistance gene.

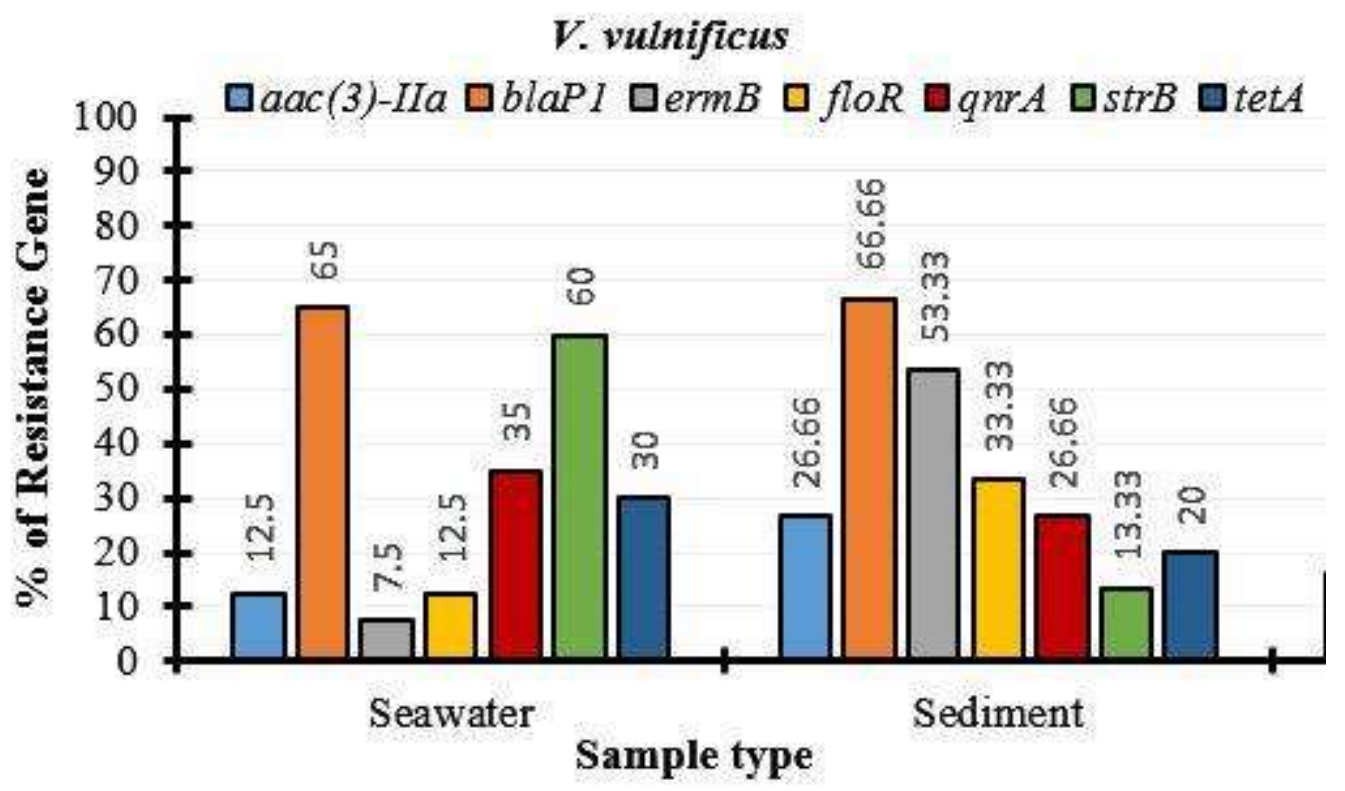

Fig 4. Percentages of seven resistance genes of $V$. vulnificus from seawater isolates from sediment and all isolates 


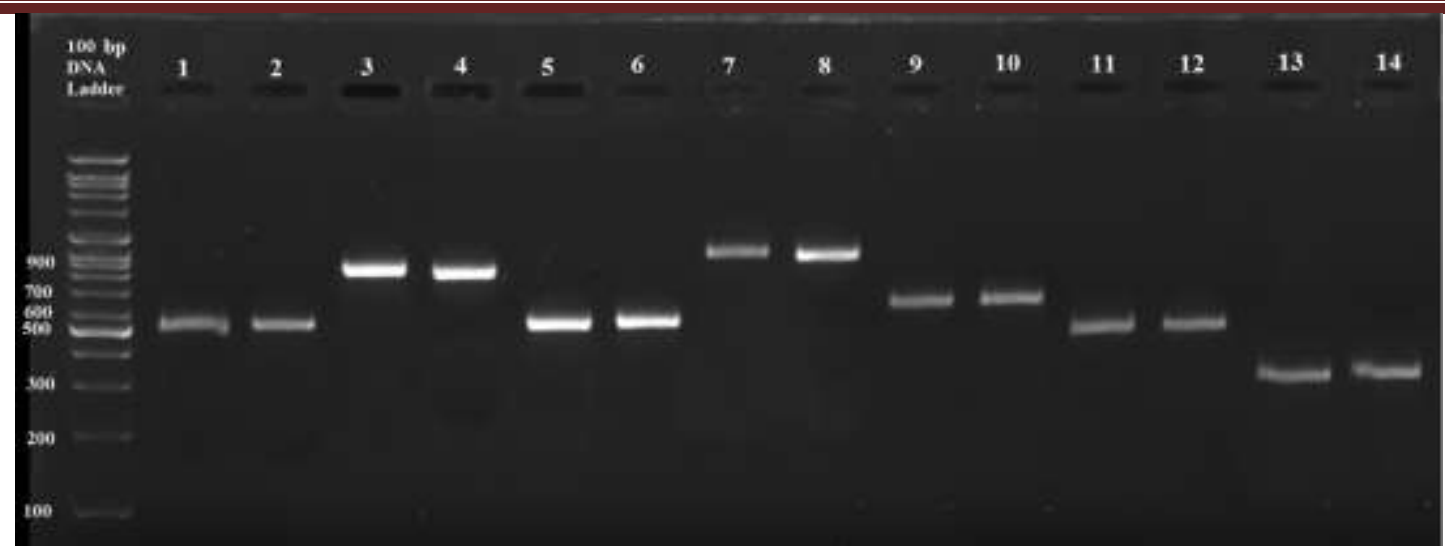

Fig 5. Detection of antibiotic resistance genes in $V$. vulnificus isolates by PCR technique, electrophoresed on $1.5 \%$ (w/v) agarose gel. Lanes 1, 2: StrB gene in VVCW2 and VVDW3.

Lanes 3, 4: blaP1 gene in VVCW5 and VVDW9. Lanes 5, 6: floR gene in VVJS2 and VVLS1. Lanes 7, 8: tetA gene in VVIW1 and VVJW3. Lanes 9, 10: ermB gene in VVDW4 and VVFW6. Lanes 11, 12: qnrA gene in VVEW1 and VVKW2. Lanes 13, 14: aac(3)-IIa gene in VVDW4 and VVFW6

Table 7. Antibiotic resistance gene patterns of $V$. vulnificus

\begin{tabular}{|lll|}
\hline Resistance Gene Profile & Isolate codes & Pattern \\
\hline aac(3)-IIa, blaP1, floR, qnrA, strB & VVEW1, VVKW2 & $\mathrm{A}$ \\
aac(3)-IIa, blaP1, ermB, floR, qnrA & VVDW4, VVEW3, VVFW6 & $\mathrm{B}$ \\
blaP1, qnrA & VVJW4, VVKW1, VVLW3 & $\mathrm{C}$ \\
blaP1, strB & VVHW6, VVIW3, VVKW3, VVLW2 & $\mathrm{D}$ \\
strB, tetA & VVAW1, VVBW1, VVCW2, VVDW3, & $\mathrm{E}$ \\
& VVDW6, VVEW2, VVGW1, VVHW3, & \\
& VVIW1, VVJW3, VVJW6, VVLW1 & \\
blaP1 & VVJW5, VVLW4 & $\mathrm{F}$ \\
blaP1, strB & VVCW3, VVKW4 & $\mathrm{G}$ \\
strB & VVAW2, VVDW5, VVHW2, VVIW5 & $\mathrm{H}$ \\
blaP1, qnrA & VVCW1, VVDW8, VVFW2, VVHW4, & $\mathrm{I}$ \\
& VVIW2, VVJW2 & \\
blaP1 & VVCW5, VVDW9 & $\mathrm{J}$ \\
aac(3)-IIa, blaP1, ermB, strB, tetA & VVDS1, VVKS2 & $\mathrm{K}$ \\
blaP1, ermB, qnrA, tetA & VVDS2 & $\mathrm{L}$ \\
blaP1, ermB, floR & VVJS2, VVLS1 & $\mathrm{M}$ \\
blaP1, ermB & VVES2 & $\mathrm{N}$ \\
blaP1 & VVHS2 & 0 \\
aac(3)-IIa, blaP1 & VVES2 & $\mathrm{P}$ \\
ermB & VVBS1, VVLS2 & $\mathrm{Q}$ \\
floR, qnrA & VVCS2, VVES1, VVIS1 & $\mathrm{R}$ \\
blaP1 & VVIS3 & $\mathrm{S}$ \\
aac(3)-IIa, blaP1 & VVES3 & $\mathrm{T}$ \\
\hline
\end{tabular}

Molecular fingerprinting of $V$. vulnificus by RAPD-PCR and ERIC -PCR Typing

The dendrogram of typeable $V$. vulnificus isolates produced from RAPD-PCR and ERIC-PCR analysis using average linkage unweighted group pair method with arithmetic averages (UPGMA) are presented in Figures 6 and 7 respectively. The RAPD-PCR analysis using average linkage unweighted group pair method with arithmetic averages (UPGMA) discriminated typeable $V$. vulnificus isolate into 6 clusters and 3 single isolates, see figure 6 . These findings are consistent with the findings of previous recearchers [46], whom reported that Vibrio vulnificus isolates were discriminated into two clusters by RAPD-PCR analysis. 
In another related study [21], $V$. vulnificus isolates were similarly discriminated into 12 clusters by RAPD-PCR analysis. In yet another study [48], V. vulnificus isolates were similarly discriminated into 13 clusters by RAPD-PCR analysis. The ERIC-PCR analysis using average linkage unweighted group pair method with arithmetic averages (UPGMA) however discriminated typeable $\mathrm{V}$. vulnificus isolates into 11 clusters and 10 single isolates, see figure 7. These results corroborate with the findings of [49], who reported that $V$. vulnificus isolates from different locations in Malaysia were discriminated into 13 clusters by ERIC-PCR analysis.

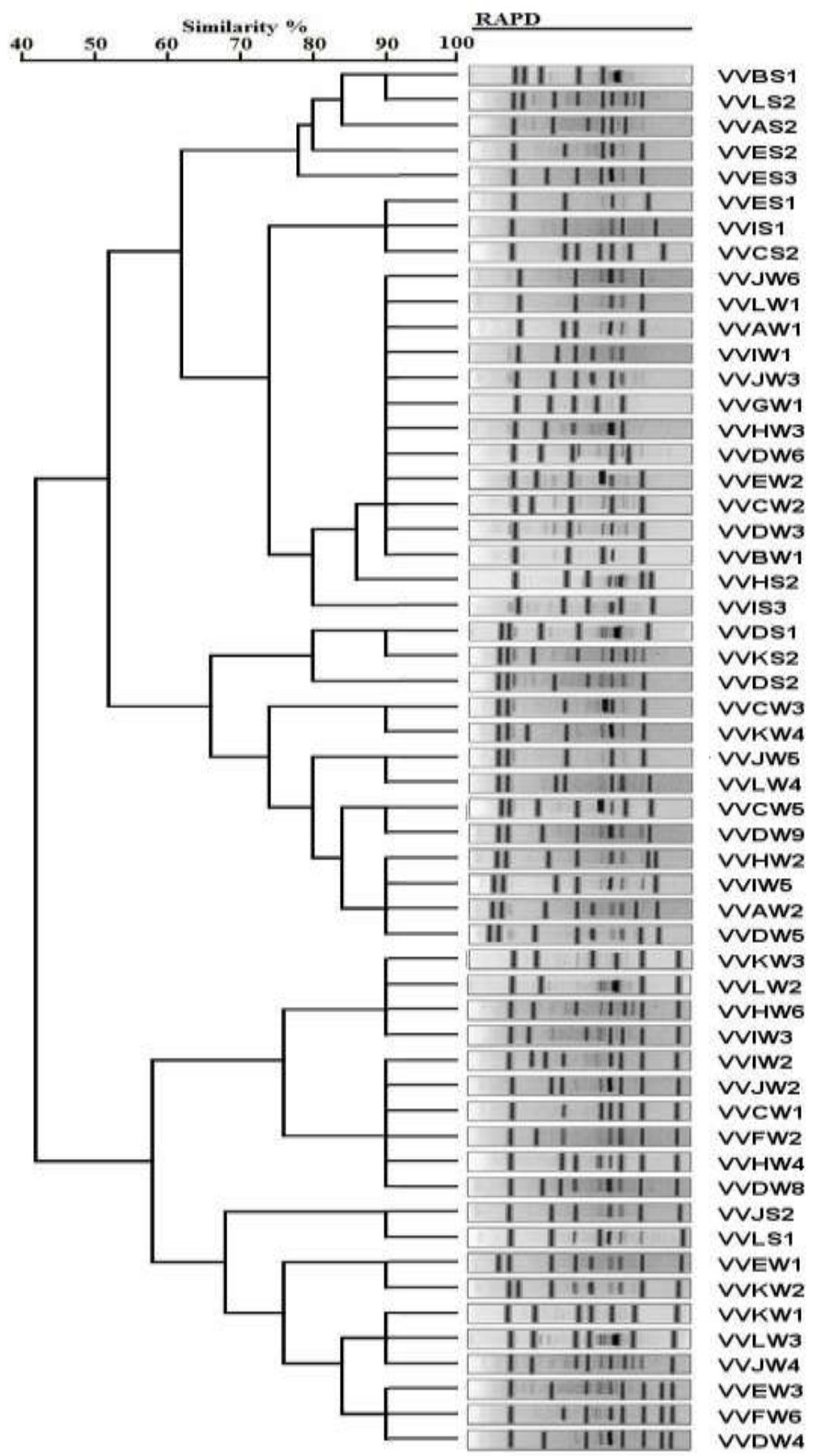

Fig 6. Dendrogram of typeable $V$. vulnificus isolates produced from RAPD analysis using average linkage unweighted group pair method with arithmetic averages (UPGMA) 


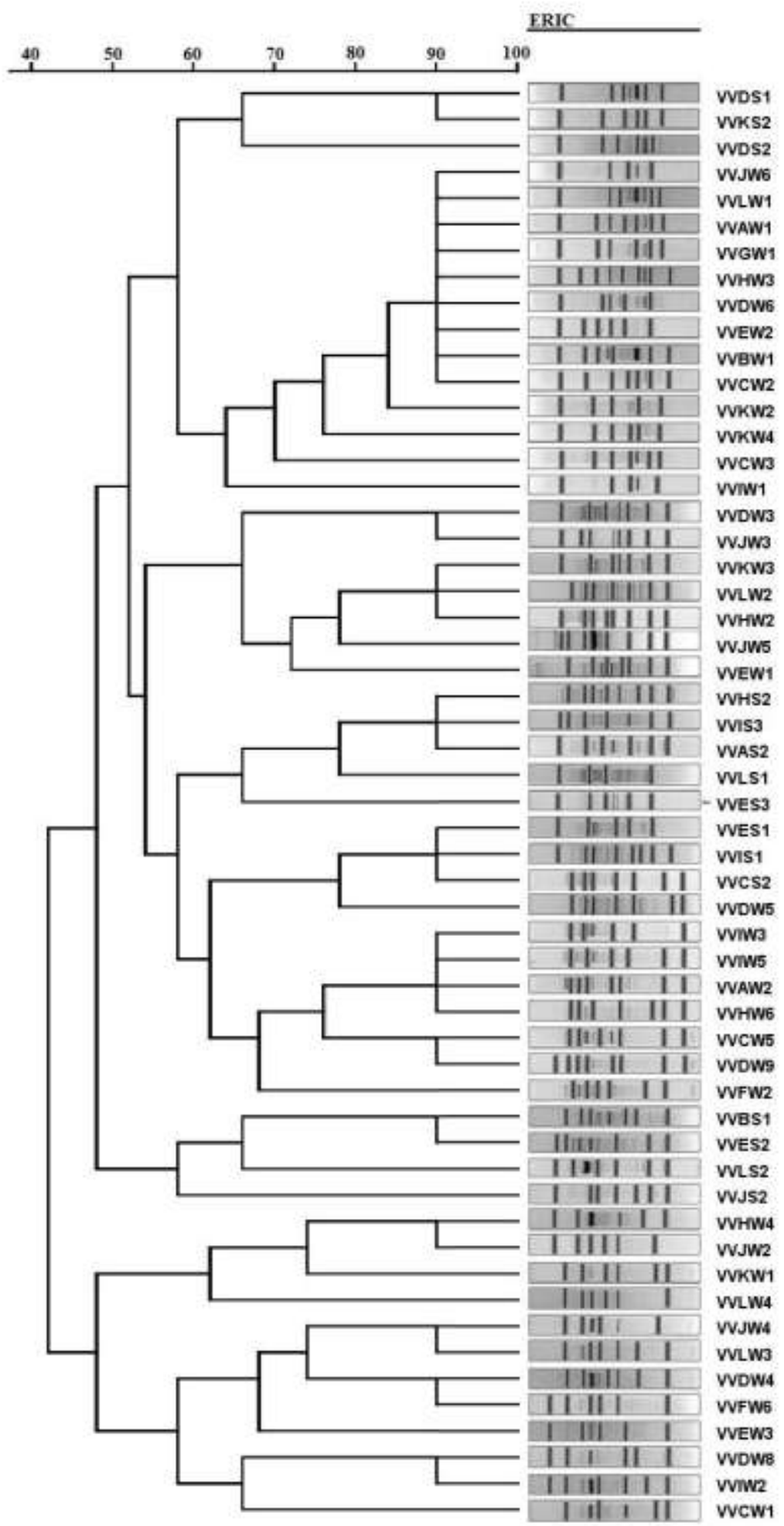

Fig 7. Dendrogram of typeable $V$. vulnificus isolates produced from ERIC analysis using average linkage unweighted group pair method with arithmetic averages (UPGMA)

\section{Acknowledgments}

The authors would like to thank the University of Kebangsaan Malaysia (UKM) for supporting this research by grants 04-01-02-SF014 from Ministry of Science, Technology and Innovation (MOSTI) of Malaysia and UKM (GUP BTK 07-75-198). 


\section{REFERENCES}

1. Miyasaka, J., Yahiro, S., Arahira, Y., Tokunaga, H., Katsuki, K., \& Hara-Kudo, Y. Isolation of Vibrio parahaemolyticus and Vibrio vulnificus from wild aquatic birds in Japan. Epidemiology \& Infection, 134(4), 780-785. 2006.

2. Vaseeharan, B., \& Ramasamy, P. Abundance of potentially pathogenic micro-organisms in Penaeus monodon larvae rearing systems in India. Microbiological research, 158(4), 299-308. 2003.

3. Chanratchakool. P. Pearson. M., Limsuwan, C. \& Roberts, Rl. Oxyletracyclinesemitivity of Vihrio species isolated from diseased black tiger shrimp. Penacusmonodon Fahricius. Journal of Fish Diseases, 18: 79-82. 1995.

4. Tison, D. L., Nishibuchi, M., Greenwood, J. D., \& Seidler, R. J. Vibrio vulnificus biogroup 2: new biogroup pathogenic for eels. Applied and Environmental Microbiology, 44(3), 640-646. 1982.

5. Amaro, C., \& Biosca, E. G. Vibrio vulnificus biotype 2, pathogenic for eels, is also an opportunistic pathogen for humans. Applied and Environmental Microbiology, 62(4), 1454-1457. 1996.

6. Bisharat, N., Cohen, D. I., Maiden, M. C., Crook, D. W., Peto, T., \& Harding, R. M. The evolution of genetic structure in the marine pathogen, Vibrio vulnificus. Infection, Genetics and Evolution, 7(6), 685-693. 2007.

7. Esteve-Gassent, M. D., \& Amaro, C. Immunogenic antigens of the eel pathogen Vibrio vulnificus serovar E. Fish \& shellfish immunology, 17(3), 277-291. 2004.

8. Grau, B. L., Henk, M. C., Garrison, K. L., Olivier, B. J., Schulz, R. M., O'Reilly, K. L., \& Pettis, G. S. Further characterization of Vibrio vulnificus rugose variants and identification of a capsular and rugose exopolysaccharide gene cluster. Infection and immunity, 76(4), 1485-1497. 2008.

9. Zuppardo, A. B., \& Siebeling, R. J. An epimerase gene essential for capsule synthesis in Vibrio vulnificus. Infection and immunity, 66(6), 2601-2606. 1998.

10. Jeong, H. G., \& Satchell, K. J. Additive function of Vibrio vulnificus MARTXVv and VvhA cytolysins promotes rapid growth and epithelial tissue necrosis during intestinal infection. PLoS pathogens, 8(3), e1002581. 2012.

11. Gray, L. D., \& Kreger, A. S. Detection of Vibrio vulnificus cytolysin in V. vulnificusinfected mice. Toxicon, 27(4), 459-464. 1989.

12. Oliver, J. D. Wound infections caused by Vibrio vulnificus and other marine bacteria. Epidemiology \& Infection, 133(3), 383-391. 2005.

13. Jeong, H. G., \& Satchell, K. J. Additive function of Vibrio vulnificus MARTXVv and VvhA cytolysins promotes rapid growth and epithelial tissue necrosis during intestinal infection. PLoS pathogens, 8(3), e1002581. 2012.

14. Lee, C. T., Amaro, C., Wu, K. M., Valiente, E., Chang, Y. F., Tsai, S. F., ... \& Hor, L. I. A common virulence plasmid in biotype 2 Vibrio vulnificus and its dissemination aided by a conjugal plasmid. Journal of bacteriology, 190(5), 1638-1648. 2008.

15. Roig, F. J., \& Amaro, C. Plasmid diversity in Vibrio vulnificus biotypes. Microbiology, 155(2), 489-497. 2009.

16. Elhadi, N. (). Antibiotic resistance and plasmid profiling of clinically significant Vibrio vulnificus isolated from coastal water in eastern province of Saudi Arabia. British Journal of Pharmacology and Toxicology, 3(2), 93-97. 2012

17. Mazel, D., \& Davies, J. Antibiotic resistance in microbes. Cellular and Molecular Life Sciences CMLS, 56(9-10), 742-754. 1999.

18. Blake, P. A., Merson, M. H., Weaver, R. E., Hollis, D. G., \& Heublein, P. C. Disease caused by a marine vibrio: clinical characteristics and epidemiology. New England Journal of Medicine, 300(1), 1-5. 1979. 
19. Ottaviani, D., Bacchiocchi, I., Masini, L., Leoni, F., Carraturo, A., Giammarioli, M., \& Sbaraglia, G. Antimicrobial susceptibility of potentially pathogenic halophilic vibrios isolated from seafood. International journal of antimicrobial agents, 18(2), 135-140. 2001.

20. Zanetti, S., Spanu, T., Deriu, A., Romano, L., Sechi, L. A., \& Fadda, G. In vitro susceptibility of Vibrio spp. isolated from the environment. International journal of antimicrobial agents, 17(5), 407-409. 2001.

21. Hoi, L., Dalsgaard, A., Larsen, J. L., Warner, J. M., \& Oliver, J. D. Comparison of ribotyping and randomly amplified polymorphic DNA PCR for characterization of Vibrio vulnificus. Applied and environmental microbiology, 63(5), 1674-1678. 1997.

22. Francy, D. S., Myers, D. N. \& Helsel, D. R. Microbiological monitoring for the us geological survey national water-quality assessment program. US Department of the Interior, US Geological Survey. 2000.

23. Elmanama, A. A., Fahd, M. I., Afifi, S., Abdallah, S. \& Bahr, S. Microbiological beach sand quality in Gaza strip in comparison to seawater quality. Environmental Research, 99(1): 1-10. 2005.

24. Jayasinghe, C., Ahmed, S. \& Kariyawasam, M. The isolation and identification of Vibrio species in marine shrimps of Sri Lanka. Journal of Food and Agriculture, 1(1): 36-44. 2010.

25. Jacobs, L. \& Chenia, H. Y. Characterization of integrons and tetracycline resistance determinants in Aeromonas spp. isolated from south african aquaculture systems. International journal of food microbiology, 114(3): 295-306. 2007.

26. Devi, R., Surendran, P. \& Chakraborty, K. Antibiotic resistance and plasmid profiling of Vibrio parahaemolyticus isolated from shrimp farms along the southwest coast of India. World Journal of Microbiology and Biotechnology, 25(11): 2005-2012. 2009.

27. Bauer, A. \& Rørvik, L. A novel multiplex PCR for the identification of Vibrio Parahaemolyticus, Vibrio Cholerae and Vibrio vulnificus. Letters in applied microbiology, 45(4): 371-375. 2007.

28. Bier, N., Diescher, S. \& Strauch, E. Multiplex PCR for detection of virulence markers of Vibrio vulnificus. Letters in applied microbiology, 60(5): 414-420. 2015.

29. Han, F. \& Ge, B. Multiplex PCR assays for simultaneous detection and characterization of Vibrio vulnificus strains. Letters in applied microbiology, 51(2): 234-240. 2010.

30. Kim, I. H., Shim, J.-I., Lee, K.-E., Hwang, W., Kim, I.-J., Choi, S.-H. \& Kim, K.-S. Nonribosomal peptide synthase is responsible for the biosynthesis of siderophore in Vibrio vulnificus Mo6-24/O. J Microbiol Biotechnol, 18(1): 35-42. 2008.

31. Natividad-Bonifacio, I., Fernández, F., Quiñones-Ramírez, E. I., Curiel-Quesada, E. \& Vázquez-Salinas, C. Presence of virulence markers in environmental Vibrio vulnificus strains. Journal of Applied Microbiology, 114(5): 1539-1546. 2013.

32. Paranjpye, R. N. \& Strom, M. S. A Vibrio vulnificus type iv pilin contributes to biofilm formation, adherence to epithelial cells, and virulence. Infection and immunity, 73(3): 1411-1422. 2005.

33. Shao, C.-P. \& Hor, L.-I. metalloprotease is not essential for Vibrio vulnificus virulence in mice. Infection and immunity, 68(6): 3569-3573. 2000.

34. Clinical and Laboratory Standards Institute Methods for Dilution Antimicrobial Susceptibility Tests for Bacteria That Grow Aerobicall. Performance standards for antimicrobial disk susceptibility tests 9th(ed.): Wayne, PA: CLSI., 2006.

35. García-Aljaro, C., Riera-Heredia, J. \& Blanch, A. R. Antimicrobial resistance and presence of the sxt mobile element in Vibrio Spp. isolated from aquaculture facilities. New Microbiol, 37(3): 339-346. 2014. 
36. Kim, H. B., Wang, M., Ahmed, S., Park, C. H., Larocque, R. C., Faruque, A. S., Salam, M. A., Khan, W. A., Qadri, F. \& Calderwood, S. B. transferable quinolone resistance in Vibrio cholerae. Antimicrobial agents and chemotherapy, 54(2): 799-803. 2010.

37. Raissy, M., Moumeni, M., Ansari, M. \& Rahimi, E. Antibiotic resistance pattern of some Vibrio strains isolated. Iranian Journal of Fisheries Sciences, 11(3): 618-626. 2012.

38. Stoll, C., Sidhu, J., Tiehm, A. \& Toze, S. Prevalence of clinically relevant antibiotic resistance genes in surface water samples collected from Germany and Australia. Environmental Science and Technology, 46(17): 9716-9726. 2012.

39. Radu, S., Elhadi, N., Hassan, Z., Rusul, G., Lihan, S., Fifadara, N., Yuherman and Purwati, E. Characterization of Vibrio vulnificus isolated from cockles (Anadara granosa): antimicrobial resistance, plasmid proфles and random amplication of polymorphic DNA analysis. FEMS Microbiol. Lett., 165, 139-143. 1998.

40. Sahilah, A. M., Audrey, L. Y. Y., Ong, S. L., Wan Sakeenah, W. N., Saiyyah, S., Norrakiah, A. S. \& Ahmad Azuhairi, A. DNA profiling among egg and beef meat isolates of Escherichia coli by enterobacterial repetitive intergenic consensus-PCR (ERIC-PCR) and random amplified polymorphic DNA-PCR (RAPD-PCR). International Food Research Journal, 17(4). 2010.

41. Versalovic, J., Koeuth, T. \& Lupski, R. Distribution of repetitive DNA sequences in eubacteria and application to finerpriting of bacterial enomes. Nucleic Acids Research, 19(24): 6823-6831. 1991.

42. Obuekwe, I. S., \& Igbinosa, E. Presence of virulence gene markers in Vibrio strains from an abattoir: Public health implications. International Journal of Infectious Diseases, 21, 100. 2014.

43. Baker-Austin, C., McArthur, J. V., Lindell, A. H., Wright, M. S., Tuckfield, R. C., Gooch, J., ... \& Stepanauskas, R. Multi-site analysis reveals widespread antibiotic resistance in the marine pathogen Vibrio vulnificus. Microbial ecology, 57(1), 151-159. 2009.

44. Elmahdi, S., Parveen, S., Ossai, S., DaSilva, L. V., Jahncke, M., Bowers, J., \& Jacobs, J. Vibrio parahaemolyticus and Vibrio vulnificus recovered from Oysters during an Oyster Relay Study. Applied and Environmental Microbiology, 84(3), e01790-17. 2018.

45. Li, J., Yie, J., Fu, W., Foo, R. W., Hu, Y., Woo, N. Y., \& Xu, H. Antibiotic resistance and plasmid profiles of Vibrio isolates from cultured Sparus sarba. Wei Sheng Wu Xue Bao= Acta Microbiologica Sinica, 39(5), 461-468. 1999.

46. Gutacker, M., Conza, N., Benagli, C., Pedroli, A., Bernasconi, M. V., Permin, L. \& Piffaretti, J. C. Population genetics of Vibrio vulnificus: identification of two divisions and a distinct eel-pathogenic clone. Applied and Environmental Microbiology, 69(6), 3203-3212. 2003.

47. Lin, M., Wu, X., Yan, Q., Ma, Y., Huang, L., Qin, Y., \& Xu, X. Incidence of antimicrobial-resistance genes and integrons in antibiotic-resistant bacteria isolated from eels and aquaculture ponds. Diseases of Aquatic Organisms, 120(2), 115-123. 2016.

48. Arias, C. R., Pujalte, M. J., Garay, E., \& Aznar, R. Genetic relatedness among environmental, clinical, and diseased-eel Vibrio vulnificus isolates from different geographic regions by ribotyping and randomly amplified polymorphic DNA PCR. Applied and Environmental Microbiology, 64(9), 3403-3410. 1998.

49. Paydar, M., \& Thong, K. L. Prevalence and genetic characterization of Vibrio vulnificus in raw seafood and seawater in Malaysia. Journal of Food Protection, 76(10), 1797-1800. 2013.

50. Ceccarelli, D., Salvia, A. M., Sami, J., Cappuccinelli, P. \& Colombo, M. M. New Cluster of Plasmid-Located Class 1 Integrons in Vibrio Cholerae O1 and a Dfra15 Cassette- 
Containing Integron in Vibrio Parahaemolyticus Isolated in Angola. Antimicrobial agents and chemotherapy, 50(7): 2493-2499. 2006.

51. Hochhut, B., Lotfi, Y., Mazel, D., Faruque, S. M., Woodgate, R. \& Waldor, M. K. Molecular analysis of antibiotic resistance gene clusters in Vibrio Cholerae O139 and O1 Sxt Constins. Antimicrobial agents and chemotherapy, 45(11): 2991-3000. 2001.

52. Iwanaga, M., Toma, C., Miyazato, T., Insisiengmay, S., Nakasone, N. \& Ehara, M. Antibiotic resistance conferred by a class i integron and SXT constin in Vibrio cholerae O1 Strains Isolated in Laos. Antimicrobial agents and chemotherapy, 48(7): 2364-2369. 2004.

53. Schmidt, A. S., Bruun, M. S., Dalsgaard, I. \& Larsen, J. L. Incidence, distribution, and spread of tetracycline resistance determinants and integron-associated antibiotic resistance genes among motile aeromonads from a fish farming environment. Applied and environmental microbiology, 67(12): 5675-5682. 2001.

54. Sutcliffe, J., Grebe, T., Tait-Kamradt, A. \& Wondrack, L. Detection of ErythromycinResistant Determinants by PCR. Antimicrobial agents and chemotherapy, 40(11): 25622566. 1996.

55. Chen, S., Zhao, S., White, D. G., Schroeder, C. M., Lu, R., Yang, H., Mcdermott, P. F., Ayers, S. \& Meng, J. Characterization of multiple-antimicrobial-resistant Salmonella serovars isolated from retail meats. Applied and environmental microbiology, 70(1): 1-7. 2004. 